\title{
Anto Raukas - an encyclopaedist in Estonian Quaternary geology
}

Academician Anto Raukas, DSc, Professor, member of many scientific and social organizations and a public figure, has been serving as Head of the Department of Quaternary Geology of the Institute of Geology, Estonian Academy of Sciences (now at Tallinn University of Technology) since 1965. During 40 years he has been a leading scientist and main organizer of activities in this field. Results of his works are summarized in more than 80 monographs, collections, and booklets (authored, compiled, and/or edited), and more than 400 scientific papers in different fields of geology, mainly Quaternary, but also in geography, environmental ecology, and nature protection. Bearing in mind the large variety of disciplines and trying to evaluate A. Raukas' role with one word, we call him an encyclopaedist. In fact, this term (compiler of an encyclopaedia) is correct also in a direct sense - he has been chief scientific editor of the Estonian Encyclopaedia since 2000 and is a compiler and co-editor of a number of recent well-known summarizing teamworks about Estonian big lakes (Peipsi, Võrtsjärv) and the "great book" of Estonian geology (Geology and Mineral Resources of Estonia, edited by A. Raukas and A. Teedumäe, Tallinn, 1997). A detailed overview of the biography and scientific activities of A. Raukas are easily found in the book Anto Raukas. Publications and Activities (Estonian Academy Publishers, Tallinn, 2000).

Anto Raukas began his scientific career at the Department of Geology of Tartu State University, from where he graduated cum laude in 1958. In the same year he continued postgraduate studies at the Institute of Geology, Estonian Academy of Sciences, as a PhD student in the field of petrography, lithology, and mineralogy. Three and a half years later he defended his Candidate's thesis "Lithology and Mineral Composition of Basal Tills in the Estonian SSR" and in 1972, the doctoral (DSc) thesis "Formation of Pleistocene Deposits and Glacial Landforms in Estonia" which later (1978) was published as a monograph.

During the following years A. Raukas organized cooperative research work in the institute and in different multinational teams and projects. In addition to lithology and mineralogy of glacial deposits mentioned above, the published results include those on stratigraphy of Quaternary sediments, topography of Estonian bedrock, evolution and geomorphology of the Quaternary cover, evolution of the Baltic Sea and its ancient coastal formations, distribution of erratic boulders, development of large lakes, protection and complex use of Estonian mineral 
resources, environmental history, and nature protection. Lately, one of his favourite subjects has been the formation of impact craters and usage of impact spherules as correlation tools.

A. Raukas has greatly contributed to science organization. In 1977 he was elected Member of the Estonian Academy of Sciences and Member of its Presidium, and he served as Deputy Scientific Secretary-General of the Academy for five years. In 1982-1989 he continued as Academician-Secretary of the Division of Biology, Geology, and Chemistry and Member of the Presidium of the Estonian Academy of Sciences. At the same time and also later he was active in a multitude of national and international commissions, task groups, and councils.

For his versatile high-level research and activities, A. Raukas has been awarded several prizes and medals. Three times (twice with colleagues) he has received the Estonian national science prize: for a series of monographs History of Geology in Estonia in 1991, for a set of publications Quaternary Geology of North-West Europe in 1996 (personal), and for a series of monographs about Lake Peipsi in 2003.

Recognition came also from abroad. A. Raukas was elected Foreign Member of the Polish Scientific Society (1987), Corresponding Member of the Geological Society of Finland (1990), Honorary Corresponding Member of the Royal Geographical Society (London, 1999), Honorary Member of the INQUA (1999), Honorary Doctor of the University of Latvia (1999).

International collaboration and the leading role of A. Raukas in different international projects should also be outlined. He has been and currently is a member of various international scientific bodies, including commissions of INQUA, for example, the Commission on Genesis and Lithology of Quaternary Deposits (Vice-President and head of a working group), the INQUA Sea Coast Commission, boards of several IGCP projects, and a NATO working group (CELIA). He is also Corresponding Member of the IUGS Commission on Geological Sciences for Environmental Planning.

During his long scientific career A. Raukas has devoted much effort to the education of students as a professor in Estonian Maritime Academy, supervisor and opponent of tens of Master's and doctoral theses, referee of papers, etc. For his scientific results and active involvement in social life, he was awarded the 3rd Class Order of the White Star in 1998.

A. Raukas celebrated his seventieth birthday on 17 February 2005. To mark this event, the current issue of the Proceedings of the Estonian Academy of Sciences. Geology was compiled in accordance with his profile. The papers were written by colleagues and students of A. Raukas, who, together with the staff of the Proceedings, wish him every success in future activities.

Dimitri Kaljo, Avo Miidel, Leili Saarse, and Alvar Soesoo 